\title{
THE INFLUENCE OF SOCIAL MEDIA FOR YOUNG GENERATION; THE POTENTIAL TO DAMAGE THE NATIONAL IDENTITY
}

\author{
Jihan Aqil Rihhadatul 'Aisy', Moses Glorino Rumambo Pandin ${ }^{2}$ \\ ${ }^{1,2}$ English Literature Department, Faculty of Humanities, Universitas Airlangga \\ ${ }^{1}$ jihan.aqil.rihhadatul-2020@fib.unair.ac.id ${ }^{2}$ moses.glorino@ @ib.unair.ac.id
}

\begin{abstract}
Online media gives impacts to each individual's life because this stage can introduce an intuitive association between two individuals who are even far apart. Although it is loved and provided advantage by almost everyone, incidentally, web-based media has another side. Various detrimental consequences of online media are difficult to avoid. The development of information is changing society. Recently, electronic media has been demonstrated to transform people's personalities into virtual ones. The human character is described in all things considered, and people also shape themselves into something that becomes a trend. This study aims to determine the influence of social media usage on national identity and determine the positive and negative consequences of using social media that can affect national identity. This study uses the Literature Review (LR) strategy through a subjective methodology, which describes the problem to be contemplated and provides answers to defeat the problem in-depth and start to finish indicated by the side effects of the examination and the hypothesis used. The use of online media among the millennial or young generation is indeed less secure than adults. It cannot be denied that online media such as mobile phones, i-pads, or other gadgets are currently critical in everyday life. In Indonesia itself, these innovation advances have a positive impact but also have detrimental consequences. People in general also still need direct communication to reduce gaps or miscommunication between networks. However, some people like to be involved in workplaces with an open culture and flexible events, which can be reached easily by online media. The high application of online media in millennials causes simple changes in these young people's intellectual, emotional, and even behavior. Many millennial generations tend to use dialects that are not known as Indonesian or even imitating (westernized) clothing. Younger people generally feel happy when imitating foreigners, while foreigners embrace a free lifestyle compared to their society, which has begun to be compromised. Overall, we also see that many millennial generations need information about the importance of Pancasila as the image of the
\end{abstract}


country, the state banner, and the state constitution.

Keywords: Social media, National identity, Indonesia, Young Generation.

\section{INTRODUCTION}

Youth consistently have an essential and indispensable role in the development of a country because they are a group of people who determine the fate of a country in the end. Moreover, in Indonesia, history records that youth associations have been effectively linked to various Indonesian culture areas from antiquity to recent times. In the month of Youth, which is celebrated in October, Zainudin Amali, as the Minister of Youth and Sports (MENPORA), always tries to motivate the soul of Indonesian Youth by welcoming the spirit to join together and fight for a better future. The past can motivate the current millennial generation to encourage this country to push the situation. We also need to survey and re-examine the relationship between young people and their commitment to the country.

Public and community authorities are welcoming young people to take part in the development of this country. Hari Sumpah Pemuda (The Youth Pledge) celebration began with the Second Youth Congress on 27-28 October 1928 in Batavia, which is the second noteworthy in Indonesia's autonomy work. The progress of information innovation in the millennial period allows individuals to get information effectively and quickly without time constraints. Time brought into the world in millennial time regards progress as a basic necessity. They cannot be separated from information and correspondence innovation. Advanced residents are accustomed to avoiding intellectual constructs, ready to complete several exercises simultaneously (1).

The millennial period refers to the various people brought into the world after Generation X, especially individuals brought into the world during the 1980 s to 2000 s. It means that the current school graduates are 19-39 years old. The millennial period is unprecedented, considering that this era is entirely different from the past, especially in development. Undoubtedly, the millennial period is not a time brought to the world by development but a time that develops with progress. This time, it really can experience the essential development and then transform into a wholly modernized progress. The millennial period 
encountered this, explaining that development progress began to develop rapidly during the 2000s; it is now that the nuances of development begin when they are young or have grown up. Undoubtedly, the millennial age is not a time brought into the world by development but a time that develops with progress (2).

Web-based media are online media that can associate customers to work together, share information, and create content. That is why the emergence of the term content creator, namely individuals who make content through online media as recordings, photos, or creations. Online media impacts an individual's life because this stage can introduce intelligent collaboration between two individuals who are even very far apart. Even though almost everyone liked and provided an advantage, incidentally, web-based media has another side. Various detrimental consequences of online media are not easy to avoid.

Twenty to thirty years of age are acceptable in taking advantage of electronic advances. With this significant progress, we partner with online media, constantly introducing ourselves to Z's youngsters and recent college graduates. This intimidation makes them feel very open to web media for quite a while through their phone or tablet; Online media commonly used by young people today such as Instagram, Facebook, Twitter, Line, and others.

Millennials' online time media seems to have become a part of everyday life, so it seems like a basic need. Online media is something that perceives the millennial era when compared to past correspondence plans that occur. The millennial generation has 3 (three) quality standards, to be precise 1) Creative who generally will consider their place, one proof is the progress of new companies and other inventive organizations that are driven by this era, 2) Confidence, which is steady and courageous in communicating a perspective, regardless, joking through electronic media, and 3) Connected, which is satisfactory in the mix, seen from the scientific perspective of various media on the web.

In addition, the development of customers with everyday correspondence situations, most of whom are young people, is a bizarre incident that is being created. Furthermore, the positive and uncomfortable results generated by online media also affect customers. Undoubtedly, this is far from the characteristics an ideal millennial age should have, mainly being reliable, energetic, reading a ton, being ready, having the right attitude, helping others, being sufficient to change, thinking clearly, being creative, and innovative. Being entirely 
environmentally centered is a lofty, well-positioned, and primary reason. Individual characters in electronic media can be both liquid and fluid. Cons through online media allow anyone to be anyone, even clients who are entirely unequal to the real world, such as managing sex and posting profile photos. Media no longer presents reality but has become a reality itself; even those in the media are more attractive than reality.

The purpose of this study is to determine what effect the use of web-based media has on national identity and to determine the positive and negative consequences of using webbased media that can affect national identity.

The formulation of the problem is:

a. How does the usage of social media affect national identity?

b. What are the positive and negative consequences of social media usage that can influence national identity?

\section{METHODS}

The method used in this research is Literature Review (LR) through a qualitative approach, which is expected to describe the issues being contemplated and provide answers to overcome these problems as a whole and inside and out as indicated by the investigation's consequences hypotheses used. The Evidence-Based Practice segment states that a Literature Review is a written review that examines distributed information across certain branches of knowledge and sometimes information over a certain period. This approach uses qualitative methods that highlight writing reviews or literature research. This research is expected to investigate information through reference books and journals of exploration, and checks are carried out around the clock.

\section{RESULT}

Changes that occur starting from progress and information, economy, socio-culture, and education require Indonesian Youth to have the decision to adjust to such rapid changes (3). Currently, online media is experiencing a time difference that is quite fast, where electronic media is regulated in several kinds, including 1) Social Networking, turning into extraordinary electronic media for correspondence and correspondence .; 2) Discuss, especially talk on the web 
media, such as Skype, Yahoo! Dispatch, Google Talk, and others; 3) Sharing, especially electronic media for sharing narrations, photos, recordings, music, and others, such as YouTube, Instagram, Scribd, Flickr, and others; 4) Publish, especially online media to share articles or reflections, such as WordPress, Wikipedia, Blogs, and others; 5) Social Game, which is a magnificent online media as a game that can be played together, such as Kongregate, Doof, and others; 6) Live Stream, especially online media for sharing openings/openings, such as Socializr, and others, and 7) Microblogs, which are online media for sharing short information or short updates for various supporters who follow/follow, such as Twitter, Plurk, Pownce, and others.

Given the latest information (January 2019) submitted by We Are Social - Hoorsuit (the main association concerned with the web and domiciled in the United States), out of the total population of Indonesia, which amounts to around 268.2 million, there are 150 million supporters. Online media elements with infiltration of about 56\%. This figure increased by 20 million supporters or 15\% from the previous year (January 2018), especially more than 130 million supporters of online media. With this reflection, online media endorsers in Indonesia can rely on electronic media for 3 hours 26 minutes. While the type/foundation of online media most visited by electronic media supporters in Indonesia, the stage most frequently visited by electronic media depends on the closest space being eased (top 5 (top five)) is YouTube (88\%), Facebook (81\%). ) Instagram. (80\%), Twitter (52\%), and LinkedIn (33\%). Meanwhile, the most frequently used depending on dispatch / VoIP (5 (five) buttons are WhatsApp (83\%), LINE (59\%), Facebook (FB) Messenger (47\%), BBM (38\%), and Skype ( 28\%). Papalia (2008) explains that children aged 2-18 years have a normal day of 6.5 hours every day using entertainment media, TV, chronicles, PC games, print media, radio, music, watching films longer than any other activity besides resting or nodding (4).

The far and wide use of web-based media in various circles shows that web-based media work has infiltrated all parts of life, especially in information. The use of online media among the millennial generation is said to be more dangerous than adults. The presence of online media can be used as another feasible technique to clarify the positive side of Pancasila. This information about Pancasila that has been implemented allows the negative impact of online media to be turned off. Most of our respondents also do not get bad influence from online media. They will generally find out the types of violations of the principles and essence of Pancasila through 
electronic media, for example, cyberbullying (5).

\section{DISCUSSION}

The far and vast turmoil of Industry 4.0 has many positive impacts, such as the inevitable progress and rapid digitization that is taking place in various parts of the world, including Indonesia. In Indonesia itself, the progress of this development has a positive, but also not good, effect because it is not challenging to disseminate it indirectly through online advances and other media so that Indonesian people need direct correspondence, which can lead to gaps or miscommunication between networks. Correspondence to these situations includes how to relate to one another. If there is a local information gap like this, it can cause social clashes. During the millennial period, innovation continues to help schedule leisure time (entertainment), work completion, and proper correspondence in supporting daily life. Media information innovation is always linked to the web to associate and fulfill one's needs to the web, such as Instagram, Facebook, Youtube, Academia.edu, Tokopedia, Traveloka, and other media. It allows one to gain level current union. Information immediately and the simplicity of delivery without distance restrictions. The trend in cyberspace is attached to the millennial style of the time conceived and filled in a period of human-made brainpower innovation - twenty to thirty-year-olds like workplaces with an open culture and customizable events, which make data recovery fast.

Figure 1. Percentage of Social Media Usage

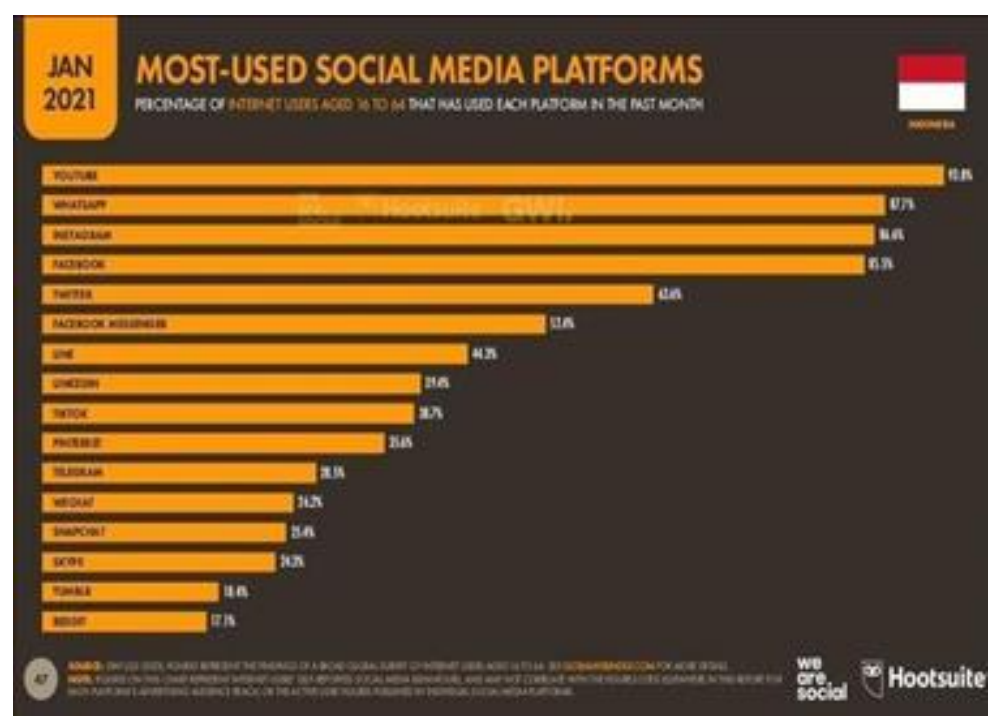


Given the repeated use from one month to the next, the most frequently used online media application in Indonesia is YouTube, followed by WhatsApp, Instagram, Facebook, and Twitter.

However, judging by the full range of online media usage where play on words, Facebook organizing is in the three major areas. Online media is WhatsApp, where Indonesian Social Media users spend an average of 30.8 hours in a month, then Facebook with 17 hours in a month, and Instagram with 17 hours consistently.

Based on research results, internet and social media users in Indonesia are pretty high. There is about 15 percent internet penetration or more than 38 million internet users, a total population of around 62 million registered and have accounts on Facebook social media. The research also shows that the average internet user in Indonesia spends nearly 3 hours connecting and surfing social media via cell phones (6).

In a report entitled Computerized 2021: The Most Later of Information into the Advanced Circumstance, it was stated that out of 274.9 million people in Indonesia, 170 million of them enjoyed the benefits of Social Media. Henceforth, the figure is around 61.8 percent.

It is unfortunate if the information transmitted is deliberate or wrong, especially as a fraud with a provocative title by readers and recipients of negative sentiment; Feelings of antagonism, criticism, and underestimating discourses that want to attack someone in particular humiliating and injuring the accountable to harm fame.

Apart from that, it can also include those around them to become overwhelmed by fear, causing mass insanity and material misfortune due to the destruction of public office. Even more so, if the information created for worthy reasons turned into ruse control, provocative features to coordinate both users and beneficiaries would benefit from negative feelings. Young people and teenagers in millennial time cannot be separated from their devices. The presence of a tool is a stress adaptation (releasing oneself from stress). When someone feels stressed in himself or when children and adolescents feel tired, one of the arrangements is a device that can help express his concerns through online media by conveying his concerns or making pictures according to the mindset he is facing. 
Nonetheless, guardians should focus that they should not use the device for two hours every day as it can affect eye health and psychological, for example, stress such as the feelings of children and adolescents who suddenly flood wildly due to the effects of playing the device for a long time. It is what needs to be considered in friendship, especially guardians, so that the use of tools that can enter online media is well controlled and managed. Because what affects changes in the current millennial period is the social climate, including innovation. Web-based media offers many conveniences that cause twenty to thirty-year-olds to feel comfortable doing so for long periods, making them dependent.

The high use of online media in the millennial era causes immediate changes in the smart, enthusiastic, and even the behavior of these young people. Various social problems have made this possible in line with the widespread use of online media among Indonesian university graduates. The maze of various information and the ignorant use of online media will have various detrimental consequences, including those related to the closed public character of the current millennial era. Etymologically, the public character comes from two individual associations, namely "character" and "public." In the book Citizenship Education for Higher Education which was dissolved by the Ministry of Research, Technology and Higher Education of the Republic of Indonesia (2016), in the preparation of Civics, the public character is closer to character, especially the trait or characteristic of assumptions or beliefs about the personality that perceives the Indonesian state from various nations. Given the state of the Indonesian state, which is public, it is clear that various nations can see and perceive the Indonesian state from different nations. The public character relates to the possibilities of a country.

According to him, the state is the nature of all people because that is where the individual gets his reality. A person will not be considered vital if they are separated from their environment (7). In the end, someone will have meaning if they appear in public. According to the relationship between nations, a person can be perceived as a nationality, considering that a nation is a brand name that distinguishes one country, Especially the traits or characteristics of assumptions or beliefs about personality that perceive the Indonesian state from various nations. Given the state of the Indonesian state, which is public, it is clear that various nations can see and perceive the Indonesian state from different nations. The public character relates to the possibilities of a country. According to him, the state is the nature of all people because that is where the 
individual gets his reality. A person will not be considered vital if they are separated from their environment (7). In the end, someone will have meaning if they appear in public. According to the relationship between nations, a person can be perceived as a nationality, considering that a nation is a brand name that distinguishes one country, Especially the traits or characteristics of assumptions or beliefs about personality that perceive the Indonesian state from various nations. Given the state of the Indonesian state, which is public, it is clear that various nations can see and perceive the Indonesian state from different nations. The public character relates to the possibilities of a country. According to him, the state is the nature of all people because that is where the individual gets his reality. A person will not be considered vital if they are separated from their environment (7). In the end, someone will have meaning if they appear in public. According to the relationship between nations, a person can be perceived as a nationality, considering that a nation is a brand name that distinguishes one country.

Table 1. Positive Effects and Negative Effects of Social Media on Adolescents

\begin{tabular}{|l|l|}
\hline $\begin{array}{l}\text { Positive Effects of Web-Based Media on } \\
\text { Adolescents }\end{array}$ & $\begin{array}{l}\text { Adverse Effects of Web-Based Media on } \\
\text { Adolescents }\end{array}$ \\
\hline
\end{tabular}


1. Growing friendship associations. Due to this restricted web-based media, it is easier for children to interact with other people across the planet. Even though most of them have never met in person.

2. The younger the age will wake up to find approaches to make themselves through the friends they meet on the web because they can get many contributions from each other.

3. Try to get information. Young people believe that getting information on the web by looking at diaries or websites is simple. In addition, electronic media can also be used as a field of information in tutoring, culture, and others.

4. The casual correspondence area makes children and adolescents better and more attentive. For example: focusing on their accomplice's birthdays, commenting on their friends' photos, chronicles, and status, maintaining good relationships even if they are not able to meet.

5. Make it easy for teens to share or share. It is easy for young people to share the basics and stuff with web journals by introducing them to a blog. a. Teens become dependent on casual network use that does not think much about time. Generally, young people who have used online media have used it for a long time.

b. In reality, young people are becoming indolent and uncooperative. The level of understanding of the language is impaired. Younger age imparts a lot to the web.

c. Relational communication climate will make children think narrower. They become ignorant about the environment around them because they contribute most of their energy to the web. It can lead to being less intense in reality.

d. Makes young people slow to think because they often use the standard network for the primary principle on the site. Facebook offers gaming support that makes young people subject to gaming.

e. Energize the tendencies of today's teens. With the arrival of online media, more and more young people are using inappropriate language. In addition, 
6. It can be used as a warning to kids adolescents who are still unfair believe that cooperating on the web. Nowadays, the language is used by young people online media offer this type of assistance today. for a limited time. Like bloggers, Facebook, Twitter, and others can post progress on these spots.
f. For children, there is no standard spelling and language other than ordinary correspondence. It makes it even more difficult for them to see correspondence in the correspondence region of the relational at significant distances and in reality.


Globalization is inevitable, will happen, and must be seen by the side-by-side view, brooding Indonesia. A nation needs to remain vigilant against expansion; trying to be great and true globalization can limit every nation to open itself in every line of life, especially in the space of issue and progress that is legal, monetary, social. Social and coherent. (Science and innovation). The presence of globalization completes a significant increase. Significant changes are changes that occur in the parts of social development that affect society. In this period of automatic society, it is very far away, and it would be not very careful for people to say that they are against progress. Improvement is the main thing, but its principal concern is to consider its size and frustration and to understand that the use of progress must be based on morals. The increase must be significant and turn into an instrument that can help work with human practices in different parts of life such as work, diversion, center, and other parts. With this limitation, it is accepted that many individuals, including younger individuals, will not face what Alwi Dahlan said, precisely the disease of information chaos (8). Information confusion is a condition that causes media groups to lose knowledge of accusations that have emerged from the media. It is good that the typical individual does not have the most dubious thoughts about what to do and how.

Indonesians born in the world around 1980 to 1995 are also touted as Millennial Time, especially those who grew up with development progress (calculating correspondence progress). The presence of millennial activities that are so familiar with the globalization environment shows that various kinds of information that are feasible can be accessed through sophisticated tools that are inserted in the public eye, as well as local territories that used to be the articulation of "information waves," namely where a person is now ready to which information can be obtained. Moreover, information is needed that must be kept away or cheated, all swallowed without going through a confirmation and certification stage first.

It cannot be denied that online media such as cellphones, iPods, and the like are currently very important in everyday life. As if people today cannot live without tools, this tool is likened to an oxygen chamber that has to be carried everywhere. Whether they neglect to bring their cell phones or not, they will try to restore them. Individuals cannot live without cell phones because 
they need to assist others wherever and whenever reliably. Like it or not, the ages of twenty to thirty need to follow the example of apparatus progress from one day to the next, with the point that dependence on such devices has antagonistic effects such as a destructive lifestyle.

Most of the twenty to thirty-year-olds cling to an unpleasant, free lifestyle. Although the freeway of life does not describe our lifestyle, it does not help us young people with any imagination what a quip - guided by the honor of eastern culture. The free life of children twenty to thirty years of age to do many things as shown by our beliefs and culture is perfect. Indeed, in the view of social defilement, behavior that should be left clean is still being penetrated and belittled. This kind of behavior cannot be allowed to continue because, in the long run, it will have an impact on society as a demonstration of self-harm which can lead to mental insufficiency. Therefore it is also essential to inculcate historical learning. Learning history will be helpful by bringing the values represented into diversity values. Thus, studying history will gain an understanding and meaning of diversity (9).

Web-based media has several capacities, including 1. Expanding human social interactions by utilizing web and web innovations; 2 and supporting the democratization of information and information; 3. Change people from message content clients to message creators themselves (10). Many millennials like to use unfamiliar dialects into Indonesian and imitate untouchable (westernized) clothing styles. When everything is said to be finished, we can see that many millennials need information about the importance of Pancasila as the country's image, the banner of the state, the state constitution, and others. In these conditions, disputes between regions, especially millennials, are driven by the growing number of millennials who are more centered on web-based media without thinking about a public character or public personality and having no information about them. Indonesian public character.

\section{CONCLUSION}

Online media is an extraordinary medium that anyone can follow and invite any interested individual to demonstrate by providing thorough investigations, providing information, and sharing information quickly and unlimited time. The media can influence the lives of individuals. Someone who starts small can become successful with online media, or vice versa. For the

environment, young people, electronic media has started to get used to it, which causes 
customers to disappear without opening the web media.

Online media influences all gatherings, especially younger ones. By Seeing the results and conversations above, online media has detrimental consequences. The younger people generally feel happy and happy when imitating foreigners, while foreigners accept a free lifestyle compared to their way of life, which has begun to develop. It cannot be denied that electronic media such as cellphones, pads, and the like today are critical in everyday life. If people today cannot live without a tool, this tool is likened to an oxygen chamber that must be distributed throughout. Whether they forget to bring their cellphones or not, they will try to restore them. They are compromised with this lifestyle. It is considered obsolete or obsolete, which can be detrimental to the public personality. Many millennial generations tend to use dialects that are not known in Indonesian and further imitate untouched (westernized) clothing.

In these conditions, conflicts between regions, especially millennials, are driven by the increasing number of millennials who are more focused on web-based media without thinking about a public character or public personality and having no information about them. Indonesian public personality. Therefore, making use of online media requires parental management and community work at a younger age. In these conditions, conflicts between regions, especially millennials, are driven by the increasing number of millennials who are more focused on webbased media without thinking about a public character or public personality and having no information about them. Indonesian public personality. Therefore, making use of online media requires parental management and community work at a younger age. In these conditions, conflicts between regions, especially millennials, are driven by the increasing number of millennials who are more focused on web-based media without thinking about a public character or public personality and having no information about them. Indonesian public personality. Therefore, making use of online media requires parental management and community work at a younger age.

However, there are many entirely plausible reasons to get most carers to restrict access to electronic media to their children. However, for children, this is also important for children who are still teenagers because, at this age, children need the full help of their parents. Nonetheless, despite all these reasons, is it true that online media will have the opposite impact on the 
advancement of Youth and Youth? If we look further, the perspective of young people is correct. Whenever it comes to the point that bodes well and suits their needs, online media can also provide many positive benefits, including young people and adolescents. Youth subs for the country, clearly Indonesia needs quality Youth.

\section{REFERENCES}

1. Pratiwi A, Asyarotin ENK. Implementasi literasi budaya dan kewargaan sebagai solusi disinformasi pada generasi millennial di Indonesia. J Kaji Inf Perpust. 2019;7(1):65-80.

2. Prasetia AR. Pengaruh Politik Identitas Melalui Media Sosial Terhadap Generasi Milenial Dan Pelaksanaan Pemilu. Conf Commun New Media Stud. 2019;21-33.

3. Sudargini Y, Purwanto A. Pendidikan Pendekatan Multikultural Untuk Membentuk Karakter dan Identitas Nasional di Era Revolusi Industri 4.0 : A Literature Review. J Ind Eng Manag Res ( Jiemar). 2020;1(3):2722-8878.

4. Ahmad A. Media Sosial dan Tantangan Masa Depan Generasi Milenial. Avant Garde. 2020;8(2):134.

5. Andrian AMP dan ALF. PENGARUH MEDIA SOSIAL TERHADAP NILAINILAI YANG TERKANDUNG DALAM PANCASILA PADA GENERASI Z. Syntax Idea. 2020;2(12):1013-9.

6. Rafiq A. Dampak Media Sosial Terhadap Perubahan Sosial Suatu Masyarakat. Glob Komunika. 2020;1(1):18-29.

7. Antari LPS. Bahasa Indonesia Sebagai Identitas Nasional Bangsa Indonesia. Stilistika [Internet].2019;8(November):92-108. Available from: http://ejournal.unibba.ac.id/index.php/jisipol/article/view/1157.

8. SARI S. Literasi Media Pada Generasi Milenial Di Era Digital. Prof J Komun dan Adm Publik. 2019;6(2):30-42. 
9. Zaenal M, Anis A, Mardiani F. Memperkuat Identitas Nasional Melalui Model Pembelajaran Berpikir Historis ( Mpbh ): Antara Nyata Atau Sebuah Asa. 2021;6(3).

10. Reiza AD. Optimalisasi Penggunaan Media Sosial Bagi Kalangan Remaja di SMA Negeri 1 Panga Aceh Barat. J Pengabdi Masy Darma Bakti Teuku Umar. 2019;1(1):74. 